\title{
DAMPAK GANGGUAN PSIKOLOGIS PENGGUNAAN PERSONAL LISTENING DEVICES (PLDs) PADA SISWA SMA DI KOTA LHOKSEUMAWE
}

\author{
Indra Zachreini* \\ Bagian Ilmu Kesehatan THT-KL Fak. Kedokteran Universitas Malikussaleh/ \\ RSUD Cut Meutia Aceh Utara \\ Corresponding author:dr_indrazachreini@yahoo.com
}

\begin{abstract}
Abstrak
Penggunaan alat bantu pendengar suara (Personal Listening Devices/PLDs) berupa headset atau earphone, akhir-akhir ni semakin marak dikalangan remaja sebagai suatu kebiasan dan gaya hidup, untuk mendengar musik baik dari handphone, ipod, walkman, MP3 player dan lain-lain. Penggunaan PLDs dalam jangka waktu lama dan intensitas tinggi dapat berdampak pada sistem auditori berupa gangguan pendengaran, namun dampak non auditori berupa gangguan psikologis akibat penggunaan PLDs belum banyak dipublikasikan. Penelitian ini bersifat observasional analitik dengan rancangan kasus kontrol. Populasi penelitian ini adalah siswa SMA di Kota Lhokseumawe. Besar sampel pada penelitian ini masing-masing kelompok 37 sampel. Tehnik pengambilan sampel secara simple random sampling. Sampel yang masuk dalam penelitian ini adalah memenuhi kriteria inklusi. Pada penelitian ini didapat bahwa terdapat perbedaan bermakna dampak gangguan psikologis seperti depresi, ansietas dan stres pada pengguna PLDs dibanding bukan pengguna PLDs dimana pada uji T didapat hasil $p$ value $0,021(p<0,05)$.
\end{abstract}

Kata Kunci: Non Auditori; Gangguan Psikologis; Personal Listening Devices 


\title{
IMPACT OF PSYCHOLOGICAL DISORDERS USE OF PERSONAL LISTENING DEVICES (PLDS) ON HIGH SCHOOL STUDENT IN LHOKSEUMAWE
}

\begin{abstract}
The using of personal listening devices (PLDs) such as headset or earphone, and nowdays increase widespreadly among teenagers as a habitual and life style, that using for listening music from hand phone, iPod, Walkman, MP3 player and others. The using of PLDs for long time and in high intensity may cause impact for auditory system such as hearing disorder, whereas non auditory impact such as psychological disorders does not publicized. This study is analytic observational by case control design. This study population is senior high school students in Lhokseumawe. The number of sample on this study is each group consist of 37 sample. Sampling taking technique on this research by simple random sampling. The including sample on this research is qualified in inclution criteria. Based on this study, there were significance difference psychological disorders impact such as depression, anxiety and stress between PLDs user than not PLDs user, which Ttest, $p$ value $0,021(p<0,05)$.
\end{abstract}

Keywords: Non Auditor;, Psychological Disorders; Personal Listening Devices 


\section{Pendahuluan}

Penggunaan alat bantu pendengar suara (Personal Listening Devices/PLDs) berupa headset atau earphone, akhir-akhir ni semakin marak dikalangan remaja sebagai suatu kebiasan dan gaya hidup, untuk mendengar musik baik dari handphone, ipod, walkman, MP3 player dan lain-lain. Bentuk PLDs dapat berupa circum-aural, supra-aural, earbud atau canalphone yang dapat mengeraskan suara kecil dari sumber suara ke telinga penggunanya. Penggunaan PLDs yang aman menurut Sound Hearing International adalah menggunakan konsep 60-60 dimana intensitas suara tidak melebihi dari $60 \%$ dan lamanya tidak melebihi dari 60 menit. ${ }^{1}$ Penggunaan PLDs dalam jangka waktu lama dan intensitas tinggi dapat berdampak pada sistem auditori berupa gangguan pendengaran. Menurut The EU's Scientific Comitte on Emerging and Newly Identified Health Risk (SCENIHR), 5-10\% pengguna PLDs berisiko kehilangan permanen bila mendengar musik lebih dari 1 jam sehari dengan intensitas suara yang tinggi dalam kurun waktu lebih dari lima tahun. $^{2}$ Rahardian pada penelitiannya membuktikan terdapat peningkatan nilai ambang dengar $20 \mathrm{~dB}$ pada kelompok kasus, sedangkan kelompok kontrol normal. ${ }^{3}$ Penelitian dampak non auditori penggunaan PLDs dikalangan remaja berupa gangguan psikologi belum banyak dipublikasikan. Dampak gangguan psikologis akibat penggunaan PLDs ini dapat berupa depresi, ansitas dan stress.

Berdasarkan uraian diatas, peneliti tertarik melakukan penelitian tentang dampak gangguan psikologi berupa depresi, ansietas dan stres, akibat penggunaan PLDs pada siswa SMA di Kota Lhokseumawe.

\section{Metode}

Penelitian ini bersifat observasional analitik dengan rancangan kasus kontrol. Populasi penelitian ini adalah siswa kelas $\mathrm{X}$, XI dan XII SMA Negeri di Kota Lhokseumawe yang terdiri dari 8 SMA Negeri. Besar sampel pada penelitian ini, menurut rumus kasus kontrol dari Lwangga dam Lameshow minimal masing-masing kelompok 37 sampel. ${ }^{4}$ Teknik pengambilan sampel secara simple random sampling. Sampel yang masuk dalam penelitian ini adalah memenuhi kriteria inklusi yaitu siswa SMA Negeri kelas X, XI dan XII serta bersedia menjadi responden. Sampel dengan hasil pemeriksaan audiogram nada murni didapat menderita ketulian, dikeluarkan dari penelitian ini.

Alat yang digunakan pada penelitian ini adalah audiometer merek GSI Arrow part 2005-0100, produksi VIASYS Healthcare USA, 2005 dan kuasioner DASS 42 dari WHO. Nilai gangguan psikologis berdasarkan kuesioner DASS 42 adalah: untuk depresi: normal (0-9), ringan (10-13), sedang (14-20), berat (21-27) dan sangat berat (lebih dari 27). Untuk ansietas: normal (0-7), ringan (8-9), sedang (10-14), berat (1519) dan sangat berat (lebih dari 19). Untuk stres: normal (0-14), sedang (15-18), berat (19-25) dan sangat berat (lebih dari 25). ${ }^{5}$

\section{Hasil Penelitian}

Pada penelitian ini didapatkan 74 sampel yang terdiri dari 37 sampel pengguna PLDs dan 37 sampel bukan pengguna PLDs. Karakteristik sampel berdasarkan jenis kelamin dapat dilihat pada tabel 1. 
Tabel 1. Jenis kelamin sampel penelitian

\begin{tabular}{lllllll}
\hline Jenis Kelamin & \multicolumn{2}{c}{ Pengguna PLDs } & \multicolumn{2}{c}{ Bukan Pengguna PLDs } & \multicolumn{2}{c}{ Total } \\
\cline { 2 - 8 } & $\mathrm{n}$ & $\%$ & $\mathrm{n}$ & $\%$ & $\mathrm{n}$ & $\%$ \\
\hline Laki-laki & 20 & 54,1 & 19 & 51,4 & 39 & 52,7 \\
Perempuan & 17 & 45,9 & 18 & 48,6 & 35 & 47,3 \\
\hline \multicolumn{1}{c}{ Total } & 37 & 100 & 37 & 100 & 37 & 100 \\
\hline
\end{tabular}

Pada tabel 1 didapatkan, pengguna PLDs dan bukan pengguna PLDs lebih banyak laki-laki dibanding perempuan.
Distribusi nilai Depression, Anxiety and Stress Scale 42 (DASS42) pada sampel penelitian dapat dilihat pada tabel 2 .

Tabel 2. Distribusi nilai DASS 42 sampel penelitian

\begin{tabular}{lccll}
\hline \multicolumn{1}{c}{ Kelompok } & Rata-rata & $\begin{array}{l}\text { Standar } \\
\text { Deviasi }\end{array}$ & $\begin{array}{l}\text { Nilai } \\
\text { Minimum }\end{array}$ & $\begin{array}{l}\text { Nilai } \\
\text { Maksimum }\end{array}$ \\
\hline Pengguna PLDs & 25,27 & 13,58 & 2 & 57 \\
Bukan Pengguna PLDs & 18,97 & 8,87 & 0 & 35 \\
\hline
\end{tabular}

Dari tabel 2 terlihat nilai rata-rata dari total nilai DASS 42 pada pengguna PLDs

Tabel 3. Nilai rata-rata DASS42

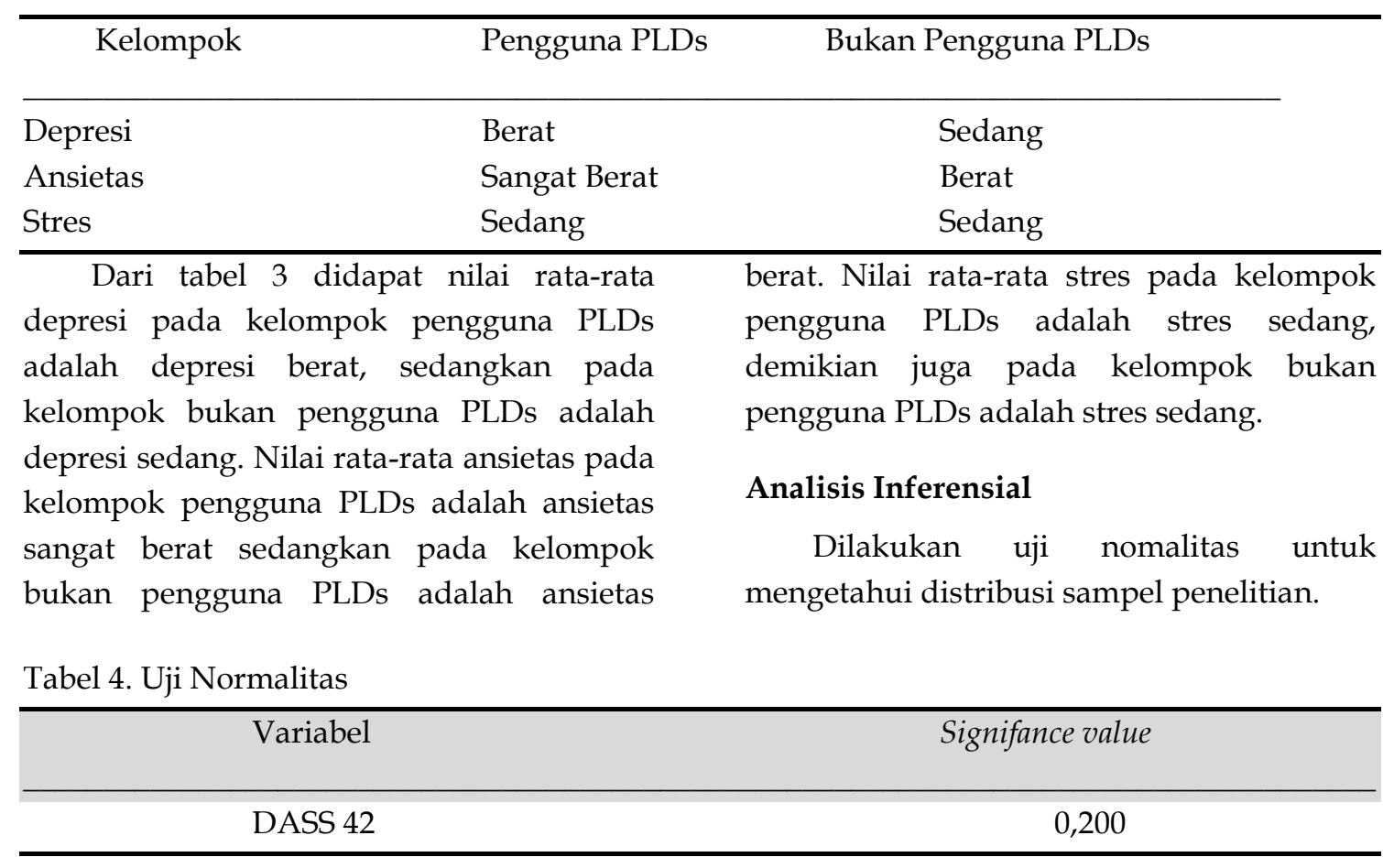

Pada tabel 4 terlihat, $p$ value $>0,05$, dimana data berdistribusi normal, sehingga valid dilakukan uji T. 
Tabel 5. Uji T

\begin{tabular}{llll}
\hline \multicolumn{1}{c}{ Nilai DASS 42 } & $\mathrm{n}$ & Mean & p value \\
\hline Pengguna PLDs & 37 & 25,27 & 0,021 \\
Bukan pengguna PLDs & 37 & 18,97 & \\
\hline
\end{tabular}

Pada tabel 5, berdasarkan uji $\mathrm{T}$ didapat $p$ value: $0,021 \quad(\mathrm{p}<0,05)$, dimana terdapat perbedaan bermakna gangguan psikologis pada kelompok pengguna PLDs dibanding kelompok bukan pengguna PLDs.

\section{Pembahasan}

Berdasarkan hasil penelitian ini didapatkan bahwa terdapat perbedaan bermakna gangguan psikologis pada pengguna PLDs dibanding bukan pengguna PLDs dimana $p$ value: 0,021 $(\mathrm{p}<0,05)$. Penelitian dampak non auditori berupa gangguan kejiwaan akibat penggunaan PLDs belum pernah dipublikasikan. Zachreini dan Putri melakukan penelitian tentang dampak non auditori berupa gangguan kejiwaan akibat paparan bising pada siswa SMK jurusan yang menggunakan tehnik mesin, mendapatkan terdapat hubungan yang bermakna paparan bising dengan gangguan kejiwaan pada siswa. ${ }^{6}$

Penelitian Fligor dan Cox mendapatkan bahwa penggunaan PLDs dengan sumber suara berasal dari streo earphone dengan volume maksimal mempunyai ambang dengar 91-121 dB dan berisiko meningkatkan ambang dengar 7-8 dB.7 Peningkatan ambang dengar tersebut bukan saja berdampak auditori seperti gangguan pendengaran, namun juga berdampak non auditori seperti gangguan psikologis berupa depresi, ansietas dan stres. ${ }^{6}$ Gangguan psikologis yang timbul akibat penggunaan PLDs dapat timbul akibat kebisingan suara melalui PLDs diteruskan dari telinga ke pusat emosi di sistem saraf pusat melalui peningkatan aktivitas aksis hypothalamus pituitary adrenalin (HPA). Hipotalamus akan merangsang sekresi kortisol sebagai efek umpan balik negatif, yang dapat menurunkan kadar corticotropin releasing factor (CRF) dan merangsang kelenjar hipofisis anterior untuk menurunkan kadar adrenocorticotropic hormon (ACTH). Bila pengguna PLDs terus terpapar suara dengan intensitas tinggi dan dalam jangka waktu lama maka mekanisme umpan balik tidak mampu lagi menekan CRF dan ACTH sehingga aktivitas aksis HPA akan meningkat terus yang mengakibatkan produksi kortisol meningkat yang dapat merusak sel-sel neuron di hipotalamus seperti atropi hipotalamus yang dapat mengakibatkan gangguan kognitif. Disamping itu, peningkatan kortisol dapat mempengaruhi kekebalan tubuh penderita dengan menekan sel T. ${ }^{8}$ Neurotrnasmiter lain yang berperan terjadinya gangguan psikologis pada pengguna PLDs adalah serotonin dan epinefrin, dimana penurunan kadar serotonin akibat paparan kebisingan dapat mencetus terjadinya gangguan psikologis. 9,10

\section{Kesimpulan Dan Saran}

Dari penelitian ini dapat disimpulkan bahwa penggunaan PLDs berdampak gangguan non auditori berupa gangguan kejiwaan seperti depresi, ansietas dan stres. Berdasarkan hasil penelitian ini, peneiti menyarankan penggunaan PLDs dikalangan remaja harus memnuhi syarat yang aman yaitu menggunakan konsep 6060. Disamping itu perlu sosialisasi tentang dampak psikologis akibat penggunaan PLDs dalam jangka waktu lama. 


\section{Daftar Pustaka}

1. Soetjipto D, 2007. Gangguan Pendengaran Akibat Bising / GPAB. Diakses 13 April 2013. Available from: URL:

http://ketulian.com/v1/web/index.p hp?to=article\&id $=15$.

2. Haines NC, Hodgets WE, Oseteovik V, Rieger JM. Listening levels of teenage ipod uses: Does measurement approach matter. University of Alberta 2012:2(6):25-30.

3. Rahadian J, Haryono R. Pengaruh penggunaan earphone terhadap fungsi pendengaran remaja. Majalah Kedokteran Indonesia 2010; 60(10):468473.

4. Madiyono B, Moeslichan S, Sastroasmoro S, Budiman I, Purwanto SH. Perkiraan besar sampel. In: Sastrooasmoro S., Ismael S, Editor). Dasar-dasar metodologi penelitian. Edisi 3, Sagung Seto, 2018; 302-30.

5. Lovibond SH, Lovibond PF. Manual for the depression anxiety stress scale. Second Edition, Psychology Foundation. Sidney, 1995.
6. Zachreini I, Putri DB. Dampak paparan bising terhadap gangguan pendengaran dan kejiwaan pada siswa SMK kabupaten Aceh Utara. Pertemuan Ilmiah Tahunan Otologi (PITO) ke-9 tahun 2014, Bandung.

7. Fligor BJ, Cox LC. Output Levels of Commercially Available Portable Compact Disc Players and The Potential Risk to hearing. Ear Hear 2004; 25(6): 513.

8. Rasmun. Pengertian stres, sumber sres dan sifat stressor. dalam: Stres, Koping, dan Adaptasi. Edisi 1. Jakarta. Sagung Seto, 2004.

9. Gunawan B, Sumadjono. Stres dan sistem imun tubuh. Dalam: Cermin Dunia Kedokteran 2007; 154.

10. Kaplan HI, Sadock BJ, Grebb JA. Sinopsis Psikiatri Jilid 2, Terjemahan Widjaja Kusuma, Jakarta: Binarupa Aksara, 2010, hal. 17-35. 